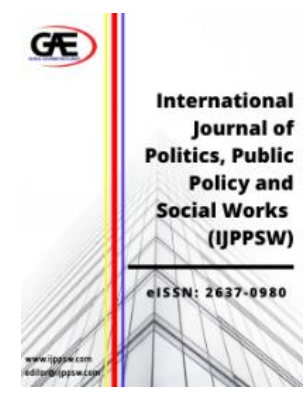

\author{
INTERNATIONAL JOURNAL OF \\ POLITICS, PUBLICS POLICY \\ AND SOCIAL WORKS \\ (IJPPSW) \\ www.ijppsw.com
}

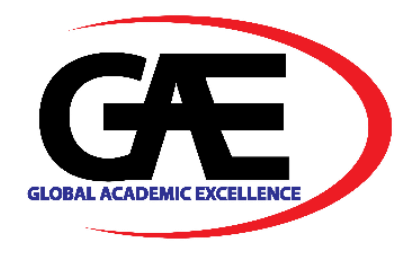

\title{
RELATIONSHIP OF SERVANT LEADERSHIP TOWARDS ORGANIZATIONAL CITIZENSHIP BEHAVIOUR (OCB) AND JOB SATISFACTION AMONG TEACHERS: A REVIEW OF LITERATURE
}

\author{
Sharifah Hamimah Shamsuddin ${ }^{1 *}$, Syed Ismail Syed Mohamad ${ }^{2}$, Zahari Hashim ${ }^{3}$
}

1 Department of Education Management, Faculty of Management and Economics, Universiti Pendidikan Sultan Idris (UPSI), 35900 Tanjong Malim, Perak.

Email: shamimjambu_radika@yahoo.com

2 Department of Education Management, Faculty of Management and Economics, Universiti Pendidikan Sultan Idris (UPSI), 35900 Tanjong Malim, Perak.

Email: syed.ismail@fpe.upsi.edu.my

3 Department of Education Management, Faculty of Management and Economics, Universiti Pendidikan Sultan Idris (UPSI), 35900 Tanjong Malim, Perak.

Email: zahari@fpe.upsi.edu.my

* Corresponding Author

\section{Article Info:}

\section{Article history:}

Received date: 01.11.2020

Revised date: 10.11 .2020

Accepted date: 02.12.2020

Published date: 10.12 .2020

To cite this document:

Shamsuddin, S. H., Mohamad, S. I. S., \& Hashim, Z. (2020). Relationship of Servant Leadership Towards Organizational Citizenship Behaviour (OCB) and Job Satisfaction Among Teachers: A Review of Literature. International Journal of Politics, Publics Policy and Social Works, 2 (7), 79-92.

DOI: 10.35631/IJPPSW.27006.
Abstract:

This paper examines the relationship between servant leadership, organizational citizenship behavior, and job satisfaction among school teachers. The first objective of the study is to explore the history, concept, and development of servant leadership, organizational citizenship behavior, and job satisfaction. The second objective is to determine previous related studies that reveal the relationship between these 3 theories towards teachers throughout the world. The third objective of the study is to focus on the relationship study between these 3 theories in the Malaysian education system. As a conclusion, this study will provide the researcher's views on why this study should be featured in the Malaysian education system.

Keywords:

Servant Leadership, OCB, Job Satisfaction, School Organization, Malaysia. 


\section{Introduction}

There are many styles of leadership that exist around the world. One of the most recognizable leadership styles is servant leadership. In the concept of the modern-day, servant leaders should become the builders of cooperation within the group beyond being a leader. The advantage of servant leadership is that it can provide a structured environment in which it places the principles in servant leadership at its core (Beazley \& Beggs, 2002). The principle of servant leadership theory is not only applicable in industrial organizations, but it is also applicable in school organizations.

In order to strengthen the quality of the nation's education, schools need to restructure their organizations to meet the demands of flexibility, quality concern and academic excellence. Today, servant leadership theory is seen as more applicable to school organizations than any other theory. This is because the organization's environment is now more likely to have leaders who serve followers. So that, followers have the opportunity to develop the potential to serve the organization and achieve better results than the results of a single leader (Ozyilmaz \& Cicek, 2015). In addition, it build strong relationships between organizational leaders and followers, thus encouraging followers to fully engage in their work whether formal or informal (Owen \& Hekman, 2015).

School organizations require teachers who are committed to the task including achievement of the school's values, objectives and goals (Runharr, Konermann \& Sanders, 2013). However, there are many factors that influence the achievement of these goals such as job satisfaction among employee's aspect. Therefore, the aspect of job satisfaction is one of the important topics in psychology. Faudziah and Nor (2012) support Bryan and Wilson's (2014) statement that there is a significant correlation between job satisfaction and job performance. In addition, the achievement of school objectives is also dependent on teacher voluntary behavior or referred to as organizational citizenship behavior (OCB) (Duyar, Ras \& Pearson, 2015).Teacher OCB is defined as the willingness of teachers to perform tasks beyond their formal responsibilities with the aim of helping schools achieve their goals (Nasra \& Heilbrunn, 2015). Previous studies have shown that OCB plays a positive role in the school climate and is an important aspect of the education sector (Christophersen, Elstad, Solhaug \& Turmo, 2015). In theory, servant leadership is seen as having a relationship on teachers' job satisfaction and OCB.

\section{History, Concept And Development Of Organizational}

\section{Servant Leadership}

Servant leadership theory was created 4 decades ago by Greenleaf (1970). Greenleaf recognizes that as the youthful revolution has been pushed by the company to be more important to the employer, one needs to lead the company where it has to change from the sole role of chairman to the co-founder of the group. Basically, Greenleaf (1970) states that there are 9 aspects of servant leadership, that is: (1) listening, (2) empathy, (3) healing, (4) awareness, (5) persuasion, 
Volume 2 Issue 7 (December 2020) PP. 79-92

DOI: 10.35631/IJPPSW.27006

(6) concept creation, (7) foresight, (8) stewardship and (9) building community to help develop other people and the community. In general, there are over 100 features of servant leadership identified in previous studies. For over two decades back, there was an increasing number of scholarly articles in servant leadership. Therefore, the dominant themes of servant leadership based on the researchers' research are summarized in Table 1.

Table 1: The Dominant Themes Of Servant Leadership Are Based On Researchers Research

\begin{tabular}{|c|c|}
\hline Researcher & Themes \\
\hline Greenleaf (1991) & $\begin{array}{l}\text { Listening skills, empathy, healing, awareness, } \\
\text { persuasion, conceptualization, foresight, } \\
\text { stewardship and building community to help } \\
\text { develop others and promoting community }\end{array}$ \\
\hline Graham (1991) & Inspiration, moral \\
\hline Buchen (1998) & $\begin{array}{l}\text { Identification, the ability to reciprocity, } \\
\text { relationship builder, preoccupation with the } \\
\text { future }\end{array}$ \\
\hline Spears (1998) & $\begin{array}{l}\text { Listening, sympathy, healing, awareness, } \\
\text { persuasion, conceptualization, foresight, } \\
\text { supervision, commitment, community }\end{array}$ \\
\hline Laub (1999) & $\begin{array}{l}\text { Giving value to people, develop people, build } \\
\text { communities, displaying originality, providing } \\
\text { leadership, sharing }\end{array}$ \\
\hline Russell (2001) & $\begin{array}{l}\text { Appreciate others, empower, vision, credibility, } \\
\text { trust, service, modeling, pioneer }\end{array}$ \\
\hline $\begin{array}{l}\text { Sendjaya, Sarros and Santora } \\
(2008)\end{array}$ & $\begin{array}{l}\text { Influence change, volunteerism, honesty, } \\
\text { spirituality, covenant relationships, moral } \\
\text { responsibility }\end{array}$ \\
\hline $\begin{array}{l}\text { Van Dierendonck and Nuijten } \\
\text { (2011) }\end{array}$ & $\begin{array}{l}\text { Empowerment, accountability, standing back, } \\
\text { humility, authenticity, courage, forgiveness, } \\
\text { stewardship. }\end{array}$ \\
\hline Focht \& Ponton (2015) & $\begin{array}{l}\text { Appreciate others, humility, listening, trust, } \\
\text { caring, honesty and transparency, services, } \\
\text { empower, serve others first, cooperation, } \\
\text { loving, learning }\end{array}$ \\
\hline \multirow[t]{3}{*}{ Joseph J. Larocci (2017) } & $\begin{array}{l}\text { Three key priorities- (developing people, } \\
\text { building a trusting team, achieving results) }\end{array}$ \\
\hline & $\begin{array}{l}\text { Three key principles - (serve first, persuasion, } \\
\text { empowerment) }\end{array}$ \\
\hline & $\begin{array}{l}\text { Three key practices - (listening, delegating, } \\
\text { connecting followers to mission) }\end{array}$ \\
\hline $\begin{array}{l}\text { Sendjaya, Sen; Eva, Nathan; } \\
\text { Butar Butar, Ivan; Robin, } \\
\text { Mulyadi; Castles, Samantha } \\
\text { (2019) }\end{array}$ & $\begin{array}{l}\text { Organizational performance, trust in the leader, } \\
\text { Commitment to the leader, helping behaviours, } \\
\text { employee engagement, organizational deviant } \\
\text { behaviours. }\end{array}$ \\
\hline
\end{tabular}


From the researcher list above, the most widely used in leadership style research around the world is by Van Dierendonck and Nuijten (2011). There are 8 themes used in his theory. The meaning of empowerment is the servant leader encourages the workers. Accountability means leaders give employees responsibilities to perform to build their confidence. Besides, standing back means leaders prioritize potential of employees first and give them the support they need. Humility shows that leaders willing to admit that nothing is perfect and they will make mistakes. The next theme is authenticity which means servant leaders need to be the first to ensure that their behavior is consistent and honest. The $6^{\text {th }}$ theme is courage which shows that leaders willing to take risks and try to do something new in their decision making. The next theme is forgiveness which means that servant leaders can be forgiven when facing employee mistakes and conflicts. The last theme is stewardship which related to social responsibility, loyalty and teamwork.

\section{Organizational Citizenship Behaviour (OCB)}

Basically, there are several behaviour researches that is almost equal with Organizational Citizenship Behaviour also known as OCB. According Muhdar (2015), this fact is based on the idea by Barnard (1938) according to concept "ready to cooperate". In addition, the idea was also inspired by Roethlisberger and Dickson (1939) relating to "cooperate informally". Additionally, Katz and Kahn (1967) has put forward ideas on the behaviour patterns of individuals. These concepts are the basic for the emergence of OCB before it be discussed in more detail in the early 1980's. They already introduce three types of behaviour as the basic for ensuring an organization to function properly that is the employees get encouragement and support to be in the system, employees can listen to instructions and perform the role required, be innovative and be able to carry out a task spontaneously. This principle not only cover all activities that can create a positive climate in the organization, even the members of the organization itself in cooperation with each other without coercion.

According to the Organ (1988), OCB is a behaviour that supports the psychological and social environment in which the occurrence of task performance. It also means that a person with high OCB does not expect a bonus payment or reciprocal as they carry out the task should exceed in the organization as voluntary. OCB has 5 dimensions of altruism, courtesy, conscientiousness, sportsmanship and civic virtue. Several measurements of a person's OCB dimension have been studied and developed. Among them were OCB dimensions stated by Podsakoff, MacKenzie, Paine \& Bachrach (2000). There were helping behavior, sportsmanship, organizational loyalty, organizational compliance, individual initiative, civic virtue and selfdevelopment. In 2013, studied by Dekas, Bauer, Welle, Kurkoski \& Sullivan show that there were several dimensions in OCB measuring (helping, voice, civic vurtue, social participation and employee sustainability). However, The Morison Scale (1995) is one of the best psychometric measures (Aldag, Ray \& Wayne, 1997). Scale measures of the five OCB dimensions of OCB are shown in Table 2. 
Volume 2 Issue 7 (December 2020) PP. 79-92

DOI: 10.35631/IJPPSW.27006

Table 2: The Scale Measures Of The OCB Dimension

\begin{tabular}{|c|c|}
\hline Dimension & Measurement \\
\hline Altruism & $\begin{array}{l}\text { - Replacing a vacation partner } \\
\text { - Helping colleague with too many } \\
\text { tasks. } \\
\text { - Assist the new colleague orientation } \\
\text { process without any coercion. } \\
\text { Take the time to help colleague } \\
\text { - with work problems. } \\
\text { Be willing to do any work without } \\
\text { being asked. } \\
\text { - Help your colleagues in other } \\
\text { departments when they have a } \\
\text { problem. } \\
\text { Help customers if they need help. }\end{array}$ \\
\hline Courtesy & $\begin{array}{l}\text { - } \begin{array}{l}\text { Be aware of changes and } \\
\text { developments } \\
\text { within } \\
\text { organization. }\end{array} \\
\text { Follow any announcement from the } \\
\text { organization. } \\
\text { Make the decisions in evaluating the } \\
\text { best for your organization. }\end{array}$ \\
\hline Conscientiousness & $\begin{array}{l}\text { - Arrive early at work } \\
\text { - Punctual. } \\
\text { - Don't spend time discussing things } \\
\text { outside the scope of your work. } \\
\text { - Come soon when needed. }\end{array}$ \\
\hline Sportsmanship & $\begin{array}{l}\text { - Do not exaggerate issues beyond his } \\
\text { or her duties. }\end{array}$ \\
\hline Civic virtue & $\begin{array}{l}\text { - Pay attention to what helps your } \\
\text { organization's image. } \\
\text { - Pay attention to meetings that are } \\
\text { considered useful } \\
\text { - Collaborate in groups }\end{array}$ \\
\hline
\end{tabular}

\section{Job Satisfaction (HERZBERG Theory)}

Generally, the terms of the word 'job satisfaction' is symbolized individual behaviour towards work and their organizations and can be identified as the emotional reactions of workers to the working environment based on real achievement compared to the estimated (Phillips \& Gully, 2012). There are various theories related to job satisfaction. However, this research was choosing Herzberg's theory as a guide in conducting this research. This theory was founded by Frederick Herzberg and assisted by Bernard Mausner and Barbara Snyderman. He created this theory after conducting a research of 203 experts account and engineers according to job satisfaction at Pittsburg in 1959. The research found that positive feeling comes when they can 
Volume 2 Issue 7 (December 2020) PP. 79-92

DOI: 10.35631/IJPPSW.27006

reach targets set by themselves and feel negative when faced with workplace environment and administrators who are not cooperative (Hampton, 1981).

Herzberg introduced two important elements in increasing employee motivation as Two Factor Theory. Based on this theory, it is divided into two groups, encouragement needs (motivators) and environmental requirements factor (hygiene). Encouragement needs factors related to positive feelings on matters relating to work. It is known as a stimulant factors or motivation internal (intrinsic) where it became a contributor to high job satisfaction. Environmental requirements factor related with work environment itself. It is known as external (extrinsic) where it caused discontent (Herzberg, 1959). According to Herzberg, these two factors do not depend on each other. Herzberg Two-Factor model is shown in Table 3.

Table 3: Herzberg Two-Factor Motivation Model

\begin{tabular}{|l|l|}
\hline Motivator factors (intrinsic) & Hygiene factor (extrinsic) \\
\hline 1.Performance & 1. Supervision \\
\hline 2.The award & 2. Working conditions \\
\hline 3. The work itself & 3. Interpersonal relationships \\
\hline 4. Responsibility & 4. Salary \\
\hline 5. Progress and recognition & $\begin{array}{l}\text { 5. Smart management from } \\
\text { the employer }\end{array}$ \\
\hline
\end{tabular}

The presence of intrinsic factors can motivate the workers. If this factors does not exist in the organization, it does not cause the employees to feel dissatisfied or not be motivated to perform their duties.However, the existence of extrinsic factors in the organization does not contribute to the rise of feelings of satisfaction among the workers, but in the absence of these factors, they can cause dissatisfaction. In conclusion, motivator or intrinsic factors can be recognized as factors contributing to job satisfaction, while hygiene or extrinsic factors are better known as dissatisfaction factors.

\section{Previous Related Studies ( Reveals on The Relationship Between These Three Theories Towards Teachers Throughout the World)}

\section{Servant Leadership in Secondary Schools}

Interpretation of servant leadership can be defined as the development and facilitation in achieving the mission and vision of development to the needs of long-term success and its execution by displaying the correct way (Ayinde, Akintayo \& Kayode, 2015). A school will be successful if it can achieve the vision and mission that has been set. The size of this success is highly dependent on the leadership mechanism that practiced in the organization involved. Leaders who do not target its own sake alone, but is more concerned with the good of their followers and organizations, will be able to stimulate an increase confidence in the organization then the higher interest of the organization (Kunze, Raes \& Bruch, 2015). An organization (school) who wanted to reach effectiveness in the pursuit of success must recognize unique talents of its employees in their efforts to help advance the organization. Leaders in particular should play a major role in helping employees to exhibit and realizing their potential (Porath, Gerbasi \& Schorch, 2015). 
Volume 2 Issue 7 (December 2020) PP. 79-92 DOI: 10.35631/IJPPSW.27006

According Syakirah, Saiful and Jefri (2016), employees (teachers) a sense rewarded by the management will be tried hardly without expecting any reward. The feeling of pleasure during work among workers is an important factor in the success of an organization chart. In addition, a research by Al-Mahdy, Al- Harthi, and Salah El-Din (2016) found that teachers' job satisfaction is highly related to the principles of servant leadership. For that reason, the servant leadership in secondary schools is very necessary as proven when once the principals are willing to serve and lead (leadership servant), it will increase the OCB teachers in positive emotions while improving job satisfaction at the highest level and makes a low working pressure (Hung, Tsai \& Wu, 2016).

\section{Organizational Citizenship Behaviour (OCB) Among Teachers}

School is an organization that depends on the willingness of teachers to work outside from their regular (Asnani \& Norsiah, 2017). The work outside from regular teacher is called as organizational citizenship behaviour (OCB) and it is an important element in predicting school performance (Duyar, Ras, \& Pearson, 2015). Feelings voluntary stints in excess of official duties is considered as an additional requirement in order to improve the effectiveness of an organization (Aini \& Mohd, 2016) including schools. Teachers who practice OCB may show features of altruism, modesty, meticulously, teamwork and pure nature in which it supports the physiological functions and the effectiveness of a school (Chun-wen Lin, 2017).

In the context of globalization, the research on OCB in school organizations have started to be attention. Most of OCB research emphasize matters related to school environment climatic influence in which it is the main thing that should be included in the school to ensure that organizational goals are achieved (Popescu \& Deaconu, 2013). According to a research conducted by Nur and Fatima (2018), there are three main factors that are very dominant in creating OCB among school teachers, that is neuroticism, openness and consensual. These factors include some features that affect the climate in the organization OCB among teacher's existence of cooperation, helpful, tolerant, freedom to give idea and flexibility.

Therefore, affinity can be connected with the existence of servant leadership needs OCB among teachers to achieve the goals of an organization (school). This coincides with the fact Marek, Karwowski, Frankowicz, Kantola, and Zgaga (2014), a citizen organization with high OCB will propel the organization to achieve its vision, mission and goals. This statement is corroborated by the findings of a survey conducted by Harris, Hinds, Manansingh, Rubino, Morote and Ed (2016) which shows that the practice of servant leadership is a major factor in influencing employee satisfaction and a major cause of their stay in the organization.

\section{Job Satisfaction Among Teachers}

Job satisfaction among teachers is an important indicator to provide a prosperous climate for teachers and pupils (Nor, Jamalul \& Ruzita, 2016). The increase in job satisfaction of teachers viewed able to motivate them to always continue in the process of improving teaching skills, create a more conducive learning environment and improve student achievement. The dimensions of job satisfaction are different between individuals (Norhazwani \& Jamalullail, 2016).

\section{Relationship of Servant Leadership and Behaviour Citizenship Organization (OCB)}

Researches related to servant leadership and OCB devoted in the organization of the school is very limited. Among the research that can be attached is a research conducted by David, Judy, 
Volume 2 Issue 7 (December 2020) PP. 79-92

DOI: 10.35631/IJPPSW.27006

Roxanne and Philip (2013), in which the research examines the relationship between principal's servant leadership with OCB and school climate carried out in Alabama. The research found the practice of servant leadership by the principal is very related to the climate of the school. It also found that the practice of servant leadership is strongly associated with the school organization OCB.

Moreover, Amos (2014) conducted an analysis of the relationship of servant leadership, OCB and effectiveness as a group in the South African school system. The researched emphasizes matters related to the role of servant leaders to promote positive behaviour in the organization. Servant leadership can shape the school climate to provide more opportunities and space in shaping or creating positive behaviors such as OCB. Next, a research conducted by Adrian Geoffrey Van Der Hoven (2016) which examines the relationship between servant leadership with trust, psychological empowerment, job satisfaction and OCB among teachers selected in the West Cape. The results from the research showed significant effects and positive relationships in the study.

Recent research carried out by Muhammad, Asma and Mushtaq (2018) related to school performance that practice servant leadership with teachers' OCB effect. Based on the results of research, show that empower employees, providing support to employees and responsible for a positive impact and very important in influencing the OCB teachers. The research also found how servant leadership affects teachers' OCB where it affects the pattern of the overall performance of the school. Based on the results of researches that have been conducted abroad that has been attached as mentioned above, it is clear that there is a significant correlation between the two variables above between servant leadership and OCB. It covers various fields including education.

\section{Relationship of Servant Leadership with Job Satisfaction}

School leader with a complex role and authority can provide an effective culture, change and innovate to school (Chatzipanayiotou, 2008). However, a leader which practice servant leadership will bring a positive impact on job satisfaction of teachers where the excess corresponding to the effectiveness and quality (Al- Mahdy Al-Harthi, \& Wrong, 2016). This statement is supported with a researched conducted by Georgolopoulos, Papaloi and Loukorou (2018) in Trikala, Greece. Research which done among teachers showed a good level of job satisfaction exist when the principals/headmasters practicing servant leadership in their schools. They believe that the task they are doing is important for their success and ultimately. They felt free to be more creative at their workplace. In conclusion, there is a strong focus in the literature servant leadership and employee satisfaction. Efforts to improve employee satisfaction can be seen when leaders show the characters of servant leadership (Mehta \& Pillay, 2011).

\section{Relationship of Job Satisfaction and OCB}

The leader of an organization is desirable to increase the level of OCB among subordinates (Davnarışı, 2014). Job satisfaction is one of the factor that can increase OCB among staff's (Hooi Lai Wan, 2016). This statement was including situation in school organization. It was supported by Robbins and Judge (2013) research which clarify that human will become more tendency to showing their OCB if they are gaining encouragement by the things they do for the organization. It will be created job satisfaction in themselves. This honour is given as appreciation of their hard work. 
Volume 2 Issue 7 (December 2020) PP. 79-92 DOI: 10.35631/IJPPSW.27006

According to Wagner and Hollenbeck (2010), OCB difficult to achieve among employees of the organization because job satisfaction does not exist in themselves. In the same year, Zienabadi (2010) also made a researched and found that intrinsic job satisfaction gave significant impact on OCB indirectly. This statement is supported by the findings of a research conducted by Landy and Conte (2010) and Riska and Umi (2018). They state that there is a positive relationship between job satisfaction and OCB. If teacher job satisfaction level is high, teacher OCB rate is also high. The dimensions of job satisfaction that greatly influence OCB rates are awards, working procedures and regulations. The results from the researched by Ulfiani (2013) to MAN teachers in South Sulawesi showed a positive and significant relationship between job satisfaction and OCB. Based on some of the findings that have been described above, it can be concluded in general that the more satisfied an employee in carrying out the task, the more able to realize the OCB in the workplace (Ulfiani (2014). However, if the job satisfaction level is low, the OCB level is also going to be low (Chasan \& Endang, 2017).

\section{The Relationship Study Between of Servant Leadership, OCB and Job Satisfaction Theories in The Malaysian Education System}

The Ministry of Malaysian Education has proposed two leadership styles which are transformative and distributive in the management of their schools through PPPM 2013-2025. However, after more than 5 years it has been introduced into the national education system, this style of leadership is seen as having some weaknesses. These are related to the psychology and job satisfaction of the teachers (Ministry of Education Malaysia, 2017). To solve this problem, a multi-dimensional leadership style is recommended as described by Muyan and Ramli in the Journal of Educational Research (2017). In this context, servant leadership is seen as more appropriate. Servant leadership has the advantage over transformative leadership where it provides greater opportunities for passive followers. While servant leadership has more potential to develop workers than distributive leadership (Hardin, 2003; Patterson, 2003). However, there is not much research on servant leadership in the context of Malaysian school since it was relatively new in this country.

Besides that, there are several researches conducted in job satisfaction of teachers in Malaysia. Among them is a research conducted by Nor Fadilah and Azlin (2014) on teachers of Sekolah Menengah Agama Bantuan Kerajaan (SABK), Negeri Sembilan. From the study, the level of teachers' job satisfaction is at a moderate level due to the 'satisfaction' is not emphasized by the principal. Nadiah and Azlin (2014) found that SMK's teachers job satisfaction level is higher than in SBP and SMKA in Seremban where it was influenced by the style of leadership and teamwork. The research conducted on primary school teachers in Temerloh showed that they have a high level of job satisfaction due to they can run errands or things they like (Jamalul, Che, Hazita \& Samsidah, 2014). In the same year, a research conducted on teachers in vocational colleges Johor showed significant correlation between job satisfaction and organizational commitment (Fatima, 2014). According to the research by Nor, Jamalul and Ruzita (2016), the teachers' job satisfaction in Ledang are at high level and there were no significant differences between job satisfaction based on the level of school achievement. While the study by Ahmad (2016) conducted in Marang, Terengganu showed a significant influence between principal leadership toward teachers' job satisfaction. 
Volume 2 Issue 7 (December 2020) PP. 79-92 DOI: 10.35631/IJPPSW.27006

However, studies on the existence of OCB among teachers in Malaysia are limited (Asnani \& Norsiah, 2017). Among the studies conducted were the top performing primary school teachers throughout Malaysia by Aini Marzita Mansor and Mohd Hasani Dali (2016). The study found that the level of OCB among respondents was high. Similar results were obtained in a study by Talebloo, Ramli Basri, Aminuddin Hassan, \& Asimiran, 2015) conducted in the state of Selangor. Contrary to the high school context, OCB among its teachers is at a moderate level (Nor Laila Elias, Zoharah Omar \& Khairuddin Idris, 2014). Based on the information above, the study among the three variables is independent. There is no research has yet been conducted in the context of the Malaysian school that combines these three variables. Therefore, the researcher proposes a study conducted on the relationship of these three variables to be conducted in Malaysia, specifically in the field of education. In the context of school, servant leadership based on moral principles is seen as more comprehensive than distributive leadership and it is further suggested that it is more in line with the school administration process (Yusuf, 2016). The article published by Winston and Ryan (2008) states that servant leadership is a global leadership pattern and should be included in leadership programs in Africa, Asia and the Mediterranean. It can be concluded that servant leadership is a new paradigm in leadership as it focuses more on the principles, beliefs and personalities of leaders (Yayan, 2010).Servant leadership is an effective model in the context of teacher leadership Bufalino (2017). Therefore, it is very important to study the relevance of these three variables in the Malaysian education system.

\section{Suggestions and Conclusion}

Based on further discussions above, it can be concluded that there is a relationship of servant leadership on organizational citizenship behaviour (OCB) and job satisfaction among teachers. However, this relationship is the result of a study from outside Malaysia only. Based on the result, the servant leadership style is seen as a multi-dimensional leadership style and it is seen as best practice to create OCB among teachers and to create job satisfaction among them which is seen as a necessary element of schooling to ensure that the vision and mission was achieved more transparently and effectively in the context of Malaysian educational system. The paper also proposed a number of topics that can be carried out so that the real objective of this research can be reach as follows:

1) Researches continue to create a questionnaire based on the truth of the original founders of instruments and validation of some experts (after processing language created) in the field.

2) The population of respondents identified and a questionnaire survey conducted on them

3) Conducting a pilot study before the questionnaire distributed to the actual population

4) Discard any items in the questionnaire were not right just after the pilot study were analysis

5) Doing actual research in the context of school-related with topics of research in Malaysia

6) Focus only to a state in Malaysia as the population because every school in Malaysia is subject to MOE in terms of administrative patterns, rules and staff selection. So, this means that researchers need only focus on population one of the states only in Malaysia where it represents the entire school in Malaysia.

\section{Reference}

Adila Hashim (2013). Leadership and motivation. DimensiKOOP, 41, 36-44.

Adrian Geoffrey Van Der Hoven. (2016). The influence of servant leadership on trust, psychological empowerment, job satisfaction and organisational citizenship 
Volume 2 Issue 7 (December 2020) PP. 79-92

DOI: 10.35631/IJPPSW.27006

behaviour on a selected sample of teachers in the Western Cape Province. (Master dissertation, University of the Western Cape, 2016).

Ahmad Yusri Ismail. (2016). Principals Leadership Styles and Teachers' Job Satisfaction at Sekolah Menengah Kebangsaan Marang, Terengganu. Proceeding of ICECRS, 1 (11), 1-3.

Aini Marzita Mansor. \& Mohd Hasani Dali. (2016). Relationship and Effects Self-Teacher Leadership Toward Organizational Citizenship Behaviour. Proceeding of ICECRS, 1 (2016), 753-768.

Aldag, Ray, Reschke, Wayne. (1997). Employee value added. New-York: Center for Organizational Effectiveness Inc.

Al-Mahdy, YF, Al-Harthi, the US, and Salah El-Din, NS (2016). Perceptions of school principals' servant leadership and their teacher's job satisfaction in Oman. Leadership and Policy in Schools, 15 (4), 543-566.

Amos, S. (2014). The Relationship Between Servant Leadership, Organizational Citizenship Behavioir and Team Effectiveness. SA Journal of Industrial Psycology, 40 (1), 110.

Asnani Bahari \& Norsiah Mat. (2017). The effect on the behaviour of servant leadership towards organizational citizenship behaviour among teachers: a conceptual model. Journal of Humanities, Language, Culture and Business, 1 (3), 44-54.

Ayinde, F., Akintayo, M., \& Kayode, F., (2015). Analysis of leadership theories in health organizations. International Journal of Research in Humanities \& Social Science, 3 (5), 31-33.

Barnard, C. (1938). The Functions of the Executive. (Pp. 3-290). Cambridge: Harvard University Press.

Beazley, H. \& Beggs, J. (2002). Teaching Servant-Leadership: Focus on Ledership, ServantLeadership for The Twenty-First Century. New York: Wiley \& Sons, Inc.

Bryan, L.K. \& Wilson, CA (2014). Women, Work-Life and Higher Education Leadership. Women in Higher Education, 23 (11), 6-7.

Buchen. I.H. (1998). Servant leadership: A model for future faculty and future institutions. Journal of Leadership Studies, 5 (1), 125-134.

Bufalino, G. (2017). Servant-leadership as an effective model for teacher leadership. European Journal of Research on Education and Teaching, 15(2), 129-136.

Chasan Nafi '. \& Endang Sri Indrawati. (2017). Relationship Between Job Satisfaction with Organizational Citizenship Behaviour of Employees CV. ELFA'S Kudus. Journal of Empathy, 7 (3), 134-145.

Chatzipanayiotou, P. (2008). The role of culture in the efficiency of the school organization. Intercultural Education and Education, 213-230.

Christophersen, K., Elstad, E., Solhaug, T., \& Turmo. A. (2015). Explaning motivational antecedents of citizenship behaviour among preservice teachers. Education Sciences, $5,126-145$.

Chun-wen Lin (2017). Modeling the Association between Deliberative Beliefs and Organizational Citizenship Behaviour among Teachers. International Education Studies, 10 (5), 188-196.

David, L., Judy, G., Roxanne, M., \& Philip, W. (2013). Relationships Among Servant Leadership, Organizational Citizenship Behaviour, and School Climate in Alabama High Schools. The University of Alabama, Proquest Dissertations Publishing, 1-113.

Davnarış1 HOV. (2014). Organizational citizenship behaviour level of nurses and effective factors. Journal of Health and Nursing Management, 1 (2), 89-98. 


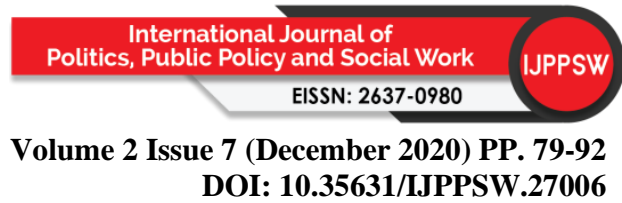

Dekas, K. H., Bauer, T. N., Welle, B., Kurkoski, J., \& Sullivan, S. (2013). Organizational citizenship behavior, version 2.0: A review and qualitative investigation of OCBs for knowledge workers at Google and beyond. The Academy of Management Perspectives, 27, 219-237.

Duyar, I., Race, N., \& Pearson, C.L. (2015). Analysis of teachers' task and extra role performance under different autonomy regimes. International Journal of Productivity and Perfi/romance Management, 64 (4), 499-522.

Fatimah Affendi (2014). Tahap Kepuasan Kerja Dan Komitmen Organisasi Dalam Kalangan Guru Kolej Vokasional. Vocational technical education undergraduate dissertation unpublished. UTHM.

Faudziah Yusof \& Nor Ba'yah Abdul Kadir (2012). Job Satisfaction, Traits Optimistic, Justice Organizations and Relationship to Job Performance. Journal of humanity, 10 (1), 6982.

Focht, A., \& Ponton, M. (2015). Identifying primary characteristics of servant leadership: Delphi study. International Journal of Leadership Studies, 9 (1), 45-61.

Georgolopoulos, V., Papaloi, E. \& Loukorou, K. (2018). Servant Leadership as a Predictive Factors of Teachers' Job Satisfaction. European Journal of Education, 1 (2), 15-28.

Graham, J.W. (1991). Servant-leadership in organizations: Inspirational and moral. Leadership Quarterly, 2 (2), 105-119.

Greenleaf, R.K. (1970), The Servant as Leader. Indianapolis, ST: The Robert K. Greenleaf Center,

Hampton, D.R. (1981). Contemporary management. New York: Mc Graw- Hill.

Hardin, F. (2003) 'Impacting Texas Public Schools Through a Student Servant Leader Model: A Case Study', Dissertation Abstracts International 64(3)

Harris, K., Hinds, L., Manansingh, S., Rubino, M., Morote, E.S. \& Ed.D. (2016). What Type of Leadership in Higher Education Promotes Job Satisfaction and Retention increases? Journal for Leadership and Instruction, 27-32.

Herzberg, F., Mausner, B., \& Snyderman, B.B. (1959). The Motivation to Work (2nd ed.). New York: John Wiley \& Sons.

Hooi Lai Wan (2016). Organizational Justice and Citizenship Behavior in Malaysia Singapore: Springer.

Hung, W. Tsai, S., And Wu, H. (2016). Relationship Among Principal ServantLeadership, School Organizational Climate and Teachers' Job Involvement of Elementary School. European Journal of Research in Social Sciences, 4 (7), 33- 42.

Jamalul Lail, A.W., Che Fuzlina, M.F., Hazita Ismail \& Samsidah Majid. (2014). Headmasters' transformational leadership and their relationship with teachers' job satisfaction and teachers' commitments. International Education Studies. 7 (13), 40-48.

Joseph J. Larocci (2017). Servant Leadership in the Workplace: A Brief Introduction. Atlanta: Cairnway.

Katz, D. and Kahn, R.L. (1967). The Social Psychology of Organization. New York: John Wiley and Sons, Inc.,

Kunze, F, Raes,F,M, \& Brunch,H. (2015). It Matter How Old You Feel: Antecedents and Performance Consequences of Age Average Relative Subjective Age In Organizations. Journal of Applied Psychology.100 (5): 1511-2.

Landy, F. J., \& Conte, J. M. (2010). Work in the 21st Century: An Introduction to Industria and Organizational Psychology (Third Edition). Hoboken, NJ: Wiley-Blackwell. 
Volume 2 Issue 7 (December 2020) PP. 79-92

DOI: 10.35631/IJPPSW.27006

Laub, J.A. (1999) 'Assessing the Servant Organization: Development of the Servant Organizational Leadership Assessment (SOLA) Instrument', Dissertation Abstracts International,60 (2).

Marek, T., Karwowski, W., Frankowicz, M., Kantola, J. \& Zgaga, P. (2014). Human factors of a global society: a system of systems perspective,477-479.

Mehta, S., \& Pillay, R. (2011). Revisiting servant leadership: An empirical study in Indian context. Journal of Contemporary Management Research, 5 (2), 24-41.

Mohd Yusri Ibrahim. \& Aziz Amin. (2014). Instructional leadership principal and teacher teaching competence. Journal of Curriculum and Instruction Asia Pacific, 2 (1).

Muhammad Nadeem Anwar, Asma Khizar. \& Mushtaq Ahmad Malik. (2016). Servant Leadership and School Performance: Mediating Effect of Teachers' Organizational Citizenship Behavior. The International Journal Research Publication's, 6 (7), 1724.

Muhdar. (2015). Organizational Citizenship Behaviour Perusahaan. IAIN SULTAN AMAI GORONTALO, Sultan Amai Press.

Muyan Alu. \& Ramli Basri (2017). Relationship of Headmaster Leadership Style Motivation Primary School Teachers in Bau, Sarawak. Journal of Educational research, 18, 2002012.

Nadiah, M.A. \& Azlin Norhaini, M. (2014). Principals transformational leadership practices and school teachers' job satisfaction excellence school in Seremban. International Seminar on Global Education II, SMEs.

Nasra, M.A., \& Heilbrunn, S. (2015). Transformational leadership and organizational citizenship behaviour in the Arab educational system in Israel: The impact of trust and job satisfaction. Educational Management Administration \& Leadership, 1-17.

Nor Fadilah \& Azlin Norhaini, M. (2014). Principals transformational leadership practices and teachers' job satisfaction at Sekolah Menengah Agama Bantuan Kerajaan (SABK) Negeri Sembilan. International Seminar on Global Education II, UKM Bangi.

Nor Mohamad Zulhairi Ismail, Jamalul Lail Abdul Wahab \& Ruzita Md Hassan. (2016). Teachers' Job Satisfaction and The Difference is based on School Achievement. Student Personnel Journal, 19 (1), 49-54.

Norhazwani Hassan \& Jamalullail, A.W. (2016). Kepuasan kerja dalam kalangan guru sekolah menengah zon Bangsar. Unpublished doctoral dissertation, Faculty of Education, Universiti Kebangsaan Malaysia.

Nur Farhah Mohd Shah. And Fatimah Wati Halim. (2018). Influence of Personality Five Factors Against Citizenship Behaviour Organization (TKO) Among Teachers. Malaysian Journal of Psychology, 32 (2), 1-11.

Organ, D.W. (1988). Organizational citizen-ship behaviour: The good soldier syndrome, Lexington, MA: Lexington Books.

Owens, B. P., \& Hekman, D.R. (2015). Modeling how to grow: An inductive examination of humble leader behaviors, contingencies, and outcomes. Academy of Management Journal, 55(4), 787-818.

Ozyilmaz, A., \& Cicek, S.S. (2015). How does servant leadership affect employee attitudes, behaviors, and psychological climates in a for-profit organizational context? Journal of Management \& Organization, 1-28.

Patterson, K.A. (2003) 'Servant Leadership: A Theoretical Model'. Dissertation Abstracts International, 64(2).

Phillips, J.M., \& Gully, S.M. (2012). Organizational behaviour: Tools for success. Mason, $\mathrm{OH}$ : South-Western. 
Volume 2 Issue 7 (December 2020) PP. 79-92

DOI: 10.35631/IJPPSW.27006

Podsakoff, P. M., MacKenzie, S. B., Paine, J. B., \& Bachrach, D. G. (2000). Organizational citizenship behaviors: A critical review of the theoretical and empirical literature and suggestions for future research. Journal of Management, 26(3), 513-563.

Popescu, A.M, \& Deaconu, A. (2013). High - school, Organizational Citizenship Behavior Moderator. Social and Behavioural Sciences, 92 (2013), 735-740,

Porath, C.L., Gerbasi, A., \& Schorch, S.L. (2015). The Effects of Civility On Advice, Leadership, and Performance. Journal of Applied Psychology. 100 (5): 1527-4.

Riska Fridiani Putri. \& Umi Anugerah Izzati. (2018). Relationship Between Satisfaction Working with Organizational Citizenship Behaviour On Teachers at Perguruan Pendidikan NU Trate (PPNUT) Gresik. Psychological Research Journal, 5 (2), 1-6.

Robbins, S.P. \& Judge, T.A. (2013). Organizational Behaviour 15th edition. England: Pearson.

Roethlisberger, F.J. \& Dickson, W.J. (1939). Management and the worker. Harvard University Press.

Sendjaya, S., Sarros, J.C., \& Santora, J.C. (2008). Defining and measuring servant leadership behavior in organizations. Journal of Management Studies, 45 (2), 402-424.

Sendjaya, S., Eva, N., Butar, I.V., Robin, M., \& Castles. S. (2019). SLBS-6: Validation of a Short Form of the Servant Leadership Behavior Scales. Journal of Business Ethics, 156(3), 1-16.

Spears, L.C. (1998). Insights on leadership: Service, stewardship, spirit, and servant leadership, New York: John Wiley and Sons.

Syakirah Ibrahim. Saiful Azley Samsudin., \& Jefri Din. (2016). Hubungan Antara Gaya Kepimpinan Servant, Penglibatan Kerja Dan Tanggapan Sokongan Organisasi Dengan Tingkahlaku Warga At Kolej Komuniti Arau. Research Gate Publication.

Ulfiani Rahman. (2014). Job Satisfaction and Organizational Citizenship Behaviour of Teachers' Madrasah Aliyah Madani Alauddin Paopao Gowa South Sulawesi. Journal "Analysis", 21 (1), 131-14.

Van Dierendonck, D., \& Nuijten, I. (2011). The servant-leadership survey (SLS): development and validation of a multidimensional measure. Journal of Business and Psychology, 26(3), 249-267,

Wagner, J.A., \& Hollenbeck, J.R. (2010). Organizational behaviour. New York: Taylor \& Francis Group.

Winston, B.E., \& Ryan, B. (2008). Servant Leadership as a Humane Orientation: Using the GLOBE Study Construct of Humane Orientation to Show that Servant Leadership is More Global than Western. International Journal of Leadership Studies, 3 (2), 212-222.

Yayan Rahayani. (2010). Servant Leadership: Educational Institution. Journal of English and Education, 4(1), 91-101.

Yusuf Cerit (2016). The Effects of Servant Leadership Behaviours of School Principals on Teachers' Job Satisfaction. Educational Management Administration \& Leadership, 37(5) 600-623.

Zeinabadi Hassanreza. (2010). Job satisfaction and organizational commitment as antecedents of Organizational Citizenship Behavior (OCB) of teachers. Procedia Social and Behavioral Science, (5), 998-1003. 